УДК 342.9:338.486.1.025.3

DOI https:// doi.org/10.32837/yuv.v0i1.1576

\author{
О. Скочиляс-Павлів, \\ кандидат юридичних наук, \\ доцент кафедри адміністративного та інформаційного права \\ Навчально-наукового інституту права, психології та інноваційної освіти \\ Національного університету «Львівська політехніка»
}

\title{
ПРАВОВІДНОСИНИ У СФЕРІ ЛІЦЕНЗУВАННЯ ЯК ОБ'ЄКТ АДМІНІСТРАТИВНО-ПРАВОВОЇ ОХОРОНИ
}

Створення правового механізму державного управління європейського типу, що забезпечує ефективну реалізацію функцій держави, передбачає комплексне оновлення форм і методів реалізації виконавчої влади. Реалізація Угоди про асоціацію між Україною, з однієї сторони, та Європейським Союзом, Європейським співтовариством 3 атомної енергії і їхніми державами-членами, з іншої сторони, не може бути зведена лише до оптимізаціï та адаптації системи державного управління до нових умов. В основі сучасних взаємовідносин виконавчої влади та суспільства в $Є C$ лежить ідея взаємовигідного співробітництва, заснована на принципі балансу публічних і приватних інтересів. Особливої актуальності за цих умов набуває дослідження ліцензування, яке, з'явившись як правова форма управління в економічній сфері, сьогодні застосовується практично у всіх сферах державного управління.

Питанню юридичної природи правовідносин у сфері ліцензування як об'єкта адміністративно-правової охорони найбільше уваги приділено в науці адміністративного права. Важливе значення для дослідження проблеми мають наукові розвідки вчених В.Б. Авер'янова, Є.В. Авер'янової, Ю.П. Битяка, А.А. Боженової, 3.С. Гладуна, І.С. Гриценка, Є.В. Додіна, М.В. Коваліва, T.О. Коломоєць, В.К. Колпакова, Є.B. Курінного, Н.M. Оніщенко, O.I. Остапенка, В.Л. Ортинського, Ю.С. Шемчушенка та ін.
Мета статті - дослідження правовідносин у сфері ліцензування як об’єкта адміністративно-правової охорони.

Дослідження ліцензування через призму функцій державного управління дає можливість сформулювати поняття ліцензування як форми реалізації виконавчої влади, щодо здійснення правового попереднього та поточного контролю за дотриманням ліцензійних вимог і умов, обліку ліцензованих об'єктів шляхом винесення органом, що ліцензує адміністративно-правових актів у межах нормативно врегульованої процедури. Елементами цієї форми $€$ орган, який ліцензує, акти ліцензування, процедура ліцензування.

Ліцензування $є$ єдиним комплексним адміністративно-правовим режимом, в основі якого лежать загальні принципи, зокрема законність, обов'язковість, публічність, заявний характер, платність, достовірність, відкритість. Особливості окремих ліцензійних режимів визначаються цільовим призначенням залежно від виду реалізованого публічного інтересу.

Правовідносини у сфері ліцензування в тій частині, що пов'язана із владно-розпорядчою діяльністю суб' $є \mathrm{~K}-$ тів державного управління, є складовою частиною предмета адміністративно-правового регулювання. Суспільні відносини, які виникають у ході ліцензування окремих видів діяльності, не тільки безпосередньо стосуються предмету адміністративно-правового регулювання, а й досить глибоко проявляються в цивільно-правовому 
та фінансово-правовому аспекті. Така ситуація робить важливим виділення адміністративно-правової складової частини цих відносин, грунтуючись на наукових положеннях про структуру предмета, вироблених наукою адміністративного права.

У ході реалізації Угоди про асоціацію між Україною, з однієї сторони, та Європейським Союзом, Європейським співтовариством 3 атомної енергіï і їхніми державами-членами [1], з іншої сторони, було закладено сучасне розуміння ліцензування, зафіксоване в законі України «Про внесення змін до деяких законодавчих актів України щодо спрощення умов ведення бізнесу (дерегуляція)», де це поняття ввійшло до змісту функцій із контролю та нагляду, які у цьому нормативному акті поділені на:

- здійснення дій контролю та нагляду за виконанням органами державної влади та місцевого самоврядування, їх посадовими особами, юридичними та фізичними особами встановлених Конституцією України, законами та іншими нормативно-правовими актами загальнообов'язкових правил поведінки;

- видачу органами державної влади та місцевого самоврядування, їх посадовими особами дозволів (ліцензій) на провадження певного виду діяльності або конкретних дій юридичним і фізичним особам;

- реєстрацію актів, документів, прав, об'єктів, видання індивідуальних правових актів [2].

До головних особливостей ліцензійного законодавства слід віднести відсутність повної систематизації та належної деталізації правил здійснення ліцензування. Відбувається це тому, що здійснення адміністративно-правової охорони суспільних відносин у сфері ліцензування грунтується на різноманітному законодавстві.

У цій сфері правового регулювання законодавцем зроблено спробу прийняття, в деякому сенсі, консолідованого законодавчого акта, яким прийнято розуміти закон «Про ліцен- зування видів господарської діяльності», що містить певний звід правил щодо тих видів діяльності, де ліцензування не відрізняється істотними особливостями [3].

До правовідносин у сфері ліцензування, на які не поширюються вимоги цього акта, належать правовідносини, пов'язані 3 ліцензуванням: використання атомної енергї; виробництва й обороту етилового спирту, алкогольної продукції; діяльності, пов'язаної із захистом державної таємниці; діяльності кредитних організацій; із проведення організованих торгів; видів професійної діяльності на ринку цінних паперів; діяльності акціонерних інвестиційних фондів, діяльності 3 управління акціонерними інвестиційними фондами, пайовими інвестиційними фондами, недержавними пенсійними фондами; діяльності спеціалізованих депозитаріїв інвестиційних фондів, пайових і недержавних пенсійних фондів; діяльності недержавних пенсійних фондів щодо пенсійного забезпечення та пенсійного страхування; клірингової, страхової, репозитарної діяльності.

Для названих видів діяльності передбачено окреме законодавче регулювання ліцензування, зближене зі загальними правилами здійснення схожих видів діяльності.

Особливості ліцензування, в т. ч. у частині, що стосується порядку прийняття рішення про надання ліцензії, терміну дії ліцензї та продовження, застосування до порушників ліцензійних вимог заходів адміністративного примусу, затверджуються в законах, які регулюють діяльність, що стосується надання послуг зв'язку, телевізійного мовлення або радіомовлення; приватної охоронної діяльності; освітньої діяльності; підприємницької діяльності, яка належить до управління багатоквартирними будинками; збору, транспортування, обробки, утилізації, знешкодження, розміщення відходів ряду класів небезпеки.

Адміністративні правовідносини у сфері ліцензування слід розглядати 


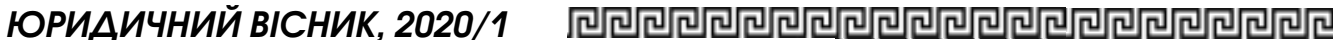

як врегульовані адміністративно-правовими нормами суспільні управлінські відносини, де у сторін є взаємні права й обов'язки, встановлені та гарантовані в адміністративно-правових нормах.

Регулятивні правовідносини у сфері ліцензування виникають у зв'язку із правомірною поведінкою учасників ліцензійної діяльності, тобто поведінкою, що виникає на основі норм законодавства про ліцензування. Регулятивні правовідносини пов'язані з реалізацією встановленого порядку видачі ліцензіі та подальшим здійсненням ліцензованої діяльності відповідно до ліцензійних умов і вимог.

Охоронні правовідносини у сфері ліцензування виникають у зв'язку 3 неправомірною діяльністю ліцензіатів - юридичних осіб, фізичних осіб-підприємців, порушенням ними законодавства про ліцензування, внаслідок чого застосовуються заходи адміністративного примусу, пов'язані, в т. ч., із призупиненням або припиненням провадження ліцензованого виду діяльності. Метою таких правовідносин $€$ захист правопорядку в ліцензійній сфері, припинення порушень ліцензійних вимог і умов, покарання правопорушника, відновлення правопорядку, який існував до порушення законодавства про ліцензування.

У науковій літературі мають місце різні підходи до визначення структури адміністративних правовідносин, під якою слід розуміти сукупність взаємопов'язаних обов'язкових елементів. Зазвичай виділяються три елементи: суб'єкти; об'єкти; нормативний зміст (права й обов'язки суб'єктів правовідносин). Іноді додатково включають умови виникнення адміністративних правовідносин - юридичні факти, правовий захист адміністративних правовідносин.

Суб'єктами адміністративних правовідносин $є$ ї учасники, тобто ті, хто наділений спеціальною компетенцією щодо державного управління (органи державного управління, посадові особи), та ті, хто має інший адміні- стративно-правовий статус (громадяни, організації, громадські об'єднання).

На думку А.А. Баженової, суб'єкти адміністративно-правового регулювання ліцензування господарської діяльності - це органи влади, які на основі норм адміністративного права та за допомогою адміністративно-правових засобів здійснюють вплив на ліцензійні відносини 3 метою забезпечення реалізації конституційного права на підприємницьку діяльність, не заборонену законом, але таку, що створює підвищений ризик заподіяння шкоди життю та здоров'ю, правам і свободам людей, навколишньому природному середовищу, безпеці держави та 3 метою запобігання шкоді життю та здоров'ю, правам і свободам людей, навколишньому природному середовищу, безпеці держави, можливість заподіяння якої пов'язана зі здійсненням суб'єктами господарювання такої діяльності [4, с. 68].

Для цілей дослідження адміністративно-правової охорони правовідносин у сфері ліцензування важливим $є$ встановлення суб'єктів, котрі, виходячи 3 характеру виконуваних функцій, представляють дві групи: суб'єкти, які мають публічно-владні повноваження, і суб'єкти, що не володіють такими. До особливої групи учасників правовідносин у сфері ліцензування слід віднести експертів.

До суб'єктів, які мають публічно-владні повноваження, належать:

1. Компетентні державні органи, наділені спеціальними повноваженнями щодо надання виключного права на конкретні види діяльності, передбачені ліцензією, з реалізації контрольно-наглядових функцій за дотриманням ліцензійних вимог i умов у процесі здійснення господарюючим або іншим суб'єктом ліцензованої діяльності.

Зазначені суб'єкти становлять найбільший інтерес, оскільки наділені повноваженнями щодо застосування заходів адміністративного примусу, передбачених у нормах законодавства, що регулює питання ліцензування 
видів господарської діяльності, законів, якими встановлюється спеціальний порядок ліцензування. До таких органів належать переважно органи виконавчої влади. Органи виконавчої влади - не просто спільність однорідних одиниць, а цілісна система, тобто така сукупність, у якій усі складові частини (окремі органи та їх структурні підрозділи) є взаємопов'язаними й водночас складають самостійні підсистеми зі своїми особливостями структури, функцій, компетенції [5, с. 25].

Поряд з органами виконавчої влади, що видають ліцензію, можуть створюватися спеціальні колегіальні органи, на які покладено прийняття рішень про видачу ліцензії. Європейська тенденція останніх років зводиться до звуження контрольних повноважень державних суб'єктів у зв'язку з діяльністю саморегулятивних організацій, державних корпорацій, позабюджетних державних фондів тощо [6, с. 99].

Крім органів виконавчої влади до суб'єктів, які здійснюють ліцензування, законодавцем віднесено Національний банк України [7].

Зазначені суб'єкти вправі застосовувати заходи державного примусу до осіб, котрі здійснюють діяльність iз порушенням ліцензійних вимог. Національний банк України здійснює ліцензування низки видів діяльності на фінансовому ринку та ринку цінних паперів, наприклад, ліцензування діяльності кредитних організацій, діяльності з проведення організованих торгів [8, с. 16].

2. Органи судової влади, уповноважені застосовувати адміністративні покарання за правопорушення у сфері ліцензування, таку примусову міру адміністративно-відновного характеру, як анулювання ліцензіі, грунтуючись на вимогах Закону «Про ліцензування видів господарської діяльності» та іншому законодавстві.

Суб’єктів ліцензійних правовідносин, що володіють публічно-владними повноваженнями, можна класифікувати за різними підставами:
1) залежно від належності до гілок державної влади: суб'єкти, які є частиною системи виконавчої влади і мають контрольно-наглядові повноваження; суб'єкти, що входять у систему судової влади; суб'єкти, що не входять у систему будь-якої гілки державної влади і наділені публічно-владними повноваженнями відповідно до законодавства;

2) залежно від способів прийняття рішень із питань застосування різних організаційних або адміністративно-примусових заходів у сфері ліцензування: суб'єкти, які приймають рішення в порядку єдиноначальності, та суб'єкти, що приймають рішення колегіально. До суб'єктів, які приймають рішення в порядку єдиноначальності, належить абсолютна більшість суб'єктів. Органи виконавчої влади спеціальної компетенції, котрі завжди (міністерства) або за загальним правилом (інші органи) приймають рішення в порядку єдиноначальності. Акти прокурорського реагування при виявленні порушень ліцензійних вимог i умов приймаються органами прокуратури в порядку єдиноначальності. Аналогічним чином приймаються різні рішення при здійсненні контрольно-наглядової діяльності у сфері ліцензування Національним банком України;

3) залежно від наявності правової можливості щодо застосування заходів адміністративного примусу: суб'єкти, які володіють такими повноваженнями (органи виконавчої влади центрального та регіонального рівнів, Національний банк України) і наділені правами щодо застосування контрольно-попереджувальних заходів, заходів адміністративного припинення й адміністративно-відновлювальних заходів; судді, котрі можуть призначати адміністративні покарання за вчинення правопорушення у сфері ліцензування та застосовувати адміністративно-відновлювальні заходи у вигляді анулювання ліцензіі; суб'єкти, що не володіють правом застосовувати заходи адміністративного примусу. 


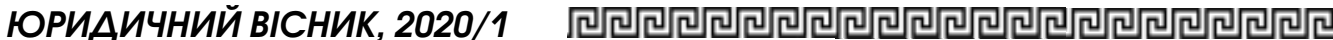

До суб'єктів, які не володіють публічно-владними повноваженнями у правовідносинах у сфері ліцензування, належать:

1. Зареєстровані в органах Державної податкової служби України юридичні і фізичні особи-підприємці, які мають відповідати певним вимогам, що пред’являються законодавством про ліцензування відповідних видів господарської діяльності. У ліцензійні правовідносини зазначені суб'єкти можуть вступати як здобувачі ліцензії (при подачі документів або при оскарженні відмови у видачі ліцензіі), та ліцензіати в разі отримання ліцензіі. Слід мати на увазі, що спеціальна правоздатність зазначених суб’єктів неоднорідна.

3 одного боку, отримуючи ліцензію, юридичні особи набувають можливість здійснювати вид діяльності, який раніше для них був недоступний. Із цього погляду законодавцем визначається єдиний момент виникнення спеціальної правоздатності - момент отримання ліцензіі. 3 іншого боку, зміст спеціальної правоздатності складають спеціальні права й обов'язки ліцензіатів.

У цьому разі вони можуть відрізнятися залежно від того, яким законодавством врегульовано ліцензування відповідного виду діяльності. Для цього має значення такий елемент спеціальної правоздатності, як обов'язок ліцензіата зазнавати несприятливих наслідків застосування заходів адміністративного примусу. Зазначені заходи, навіть маючи однакове або схоже найменування (наприклад, призупинення дії або анулювання (відкликання) ліцензіі), належать до різних класифікаційних груп заходів адміністративного примусу, застосовуються за різними фактичними підставами, різними суб' $є \mathrm{~K}-$ тами у неоднаковому процесуальному порядку, що суттєво впливає на зміст спеціальної правоздатності ліцензіатів.

2. Представники. $\mathrm{У}$ ліцензійних правовідносинах представниками $€$ фізичні особи, які вирішують організаційні питання від імені претендента на отримання ліцензії (подача заяви, подання доказів). Це можуть бути суб'єкти, котрі надають професійну юридичну допомогу (наприклад, адвокати), участь яких обмежена сферами, в яких потрібна особиста участь здобувача ліцензіі.

Спеціальні норми в законодавстві про ліцензування, що визначають повноваження представників, відсутні, а їхня участь у цих правовідносинах зумовлено положеннями цивільного законодавства про представництво.

Експерти можуть стати учасниками правовідносин у сфері ліцензування при вирішенні питання про видачу ліцензії та при здійсненні ліцензійного контролю. Їх слід виділяти як особливу групу учасників правовідносин у сфері ліцензування. Це пов'язано з тим, що експерти можуть бути посадовими особами суб'єктів державного управління, що здійснюють ліцензування та ліцензійний контроль, через що їх діяльність є складовою частиною реалізації публічно-владних повноважень.

Об'єктами адміністративних правовідносин виступає все те, із приводу чого ці відносини можуть виникнути, скластися та розвиватися. Об'єктами адміністративних правовідносин можуть бути дії та поведінка особи; державне, комунальне та приватне майно (реєстрація, вилучення, конфіскація, приватизація); предмети духовної культури тощо.

Особливості адміністративних правовідносин у сфері ліцензування полягають у тому, що вони спочатку виникають із приводу отримання ліцензії здобувачем. Одним із об'єктів таких правовідносин $є$ ліцензія, якою є спеціальний дозвіл на право здійснення юридичною або фізичною особою-підприємцем конкретного виду діяльності (виконання робіт, надання послуг, що становлять ліцензований вид діяльності), що підтверджується документом, виданим органом, який ліцензує на паперовому носії або у формі електронного документа, підписаного електронним підписом.

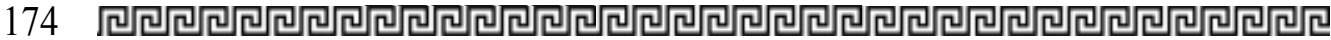


Після отримання ліцензії здобувачем і початку здійснення ліцензованого виду діяльності правовідносини у сфері ліцензування змінюються, об'єктом стає встановлений нормативно-правовими актами порядок здійснення ліцензованого виду діяльності.

У цьому разі випадку адміністративні правовідносини виникатимуть із приводу дотримання ліцензіатом вимог і умов ліцензії, що характеризує їх як контрольно-наглядові відносини, у межах яких застосовуються контрольно-попереджувальні заходи (контрольно-наглядові перевірки), заходи адміністративного припинення (видача розпоряджень про необхідність усунути порушення ліцензійних вимог), заходи забезпечення провадження у справах про адміністративні правопорушення (тимчасова заборона діяльності), адміністративні покарання, заходи адміністративного відновлення (призупинення дії ліцензії та анулювання). На думку Є.В. Авер'янової, контрольно-наглядова діяльність у сфері ліцензування господарської діяльності здійснюється у трьох напрямах - щодо додержання законності органами ліцензування, щодо наявності у суб'єктів господарювання необхідних ліцензій і щодо дотримання ліцензіатами ліцензійних умов [9, с. 86].

Змістом адміністративних правовідносин у сфері ліцензування є суб'єктивні права та юридичні обов'язки вище перерахованих суб'єктів цих правовідносин, які регламентовані в законі «Про ліцензування видів господарської діяльності» і в законах, що визначають спеціальний порядок ліцензування деяких інших видів діяльності.

Відповідно до закону «Про ліцензування видів господарської діяльності» посадові особи, які видають ліцензії, при здійсненні ліцензування мають право: вимагати від органів державної влади та місцевого самоврядування, здобувачів ліцензій і ліцензіатів, отримувати від них відомості та документи, що необхідні для здійснення ліцензування та подання яких передбачено законодавством України; проводити перевірки здобувачів ліцензій і ліцензіатів; видавати ліцензіатам приписи про усунення виявлених порушень ліцензійних вимог; застосовувати заходи для припинення адміністративних правопорушень і притягнення винних у вчиненні осіб до адміністративної відповідальності. На посадових осіб, які видають ліцензії, покладено обов'язки: виконувати своєчасно та повною мірою надані повноваження у сфері ліцензування; дотримуватися законодавства України, захищати права та законні інтереси претендентів ліцензій і ліцензіатів.

В обов'язки ліцензіата у процесі здійснення ліцензованого виду діяльності входить неухильне дотримання вимог і умов, зафіксованих під час видачі ліцензії, виконання приписів органів, що видають ліцензії, які виявили порушення та вимагають усунення, та ін. [3].

За результатами дослідження правових відносин у сфері ліцензування як об’єкта адміністративно-правової охорони можна зробити висновки:

- адміністративно-правову охорону суспільних відносин у сфері ліцензування можливо здійснювати в межах, обмежених зовні управлінською організаційно-владною діяльністю суб'єктів виконавчої влади та ряду інших публічно-владних суб'єктів, грунтуючись на сукупності законодавчих актів, норми яких спрямовані на регулювання власне ліцензування й окремих видів діяльності, що підлягають ліцензуванню;

- адміністративно-правові відносини у сфері ліцензування $є$ врегульованими адміністративно-правовими нормами суспільними відносинами, сторони яких є носіями взаємних прав і обов'язків, встановлених і гарантованих в адміністративно-правових нормах законодавства про ліцензування і прийнятих на їх виконання підзаконних нормативно-правових актах, деяких інших законодавчих актах;

- адміністративно-правові відносини у сфері ліцензування як об'єкт адміністративно-правової охорони 
мають традиційну структуру, що включає: суб'єкти, об'єкти, зміст правовідносин, юридичні факти, які зумовлюють виникнення, зміну та припинення ліцензійних правовідносин, їх правовий захист;

- суб’єкти таких правовідносин, виходячи 3 характеру виконуваних функцій, поділяються на три групи: наділені публічно-владними повноваженнями; не наділені такими; особливу групу складають експерти, котрі можуть стати учасниками правовідносин у сфері ліцензування як при вирішенні питання про видачу ліцензіі, так при здійсненні ліцензійного контролю.

Розглянуто актуальні питання правових відносини у сфері ліцензування як об'єкта адміністративно-правової охорони. Вказано, що дослідження лічензування через призму функиій державного управління дає можливість сформулювати поняття ліцензування як форми реалізації виконавчої влади щьооо здійснення правового попереднього та поточного контролю за дотриманням лічензійних вимог $i$ умов, обліку ліцензованих об'єктів шляхом винесення органом, що ліцеензує, адміністративно-правових актів у межах нормативно врегульованоі процедури. Комплексно досліджено проблеми адміністративно-правових відносин, що виникають у галузі ліцензування. На основі аналізу наукової літератури визначено поняття адміністративно-правових відносин у галузі ліщензування, під якими сліо розуміти врегульовані адміністративно-правовими нормами суспільні відносини, сторони яких є носіями взаємних прав і обов'язків, встановлених $i$ гарантованих в адміністративно-правових нормах законодавства про лічензування. Також описано характерні особливості адміністративно-правових відносин у галузі ліщензування. Наголошено, що до структури адміністративно-правових відносин у галузі ліценн- зування входять суб'єкти, об'єкти правовідносин $i$ їх нормативний зміст. Розглянуто питання класифікацї суб’єктів адміністративних правовідносин щзодо ліцеензування. Наведено три групи суб'єктів адміністративних правовідносин: наділені публічно-владними повноваженнями; не наділені публічно-владними повноваженнями; експерти. Акиентується увага на важливості формування системи суб'єктів адміністративного процесу у галузі ліщензування. Досвід правозастосовчої діяльності свідчить про те, що взаємодія суб'єктів ліцензійних правовідносин не забезпечує ефективного вирішення завдань за умов соціально орієнтованої економіки.

Ключові слова: адміністративно-правові відносини, ліцензування, суб'єкти, особливості правовідносин, охорона.

Skochylias-Pavliv O. Legal relations in the sphere of licensing as an object of administrative and legal protection

Topical issues of legal relations in the sphere of licensing as an object of administrative and legal protection are considered. It is stated that the study of licensing through the prism of public administration functions gives an opportunity to formulate the concept of licensing as a form of implementation of the executive power in the exercise of legal preliminary and current control over compliance with licensing requirements and conditions, accounting of licensed objects by issuing a body licensing administrative and legal acts in within the framework of the regulatory procedure. The problems of administrative and legal relations arising in the sphere of licensing have been comprehensively investigated. On the basis of the analysis of the scientific literature, the concept of administrative and legal relations in the field of licensing is defined, under which should be understood the public relations regulated by administrative 
and legal norms, the parties of which are the holders of mutual rights and obligations established and guaranteed in the administrative and legal norms of the licensing legislation. Characteristic features of the administrative and legal relations in the sphere of licensing are also described. It is emphasized that the structure of administrative and legal relations in the field of licensing includes subjects, objects of legal relations and their normative content. The classification of subjects of administrative legal relations concerning licensing is considered. There are three groups of subjects of administrative legal relations: endowed with public authority; not endowed with public authority; experts. Emphasis is placed on the importance of forming a system of subjects of the administrative process in the sphere of licensing. The experience of law enforcement activities shows that the interaction of the subjects of licensed legal relations does not provide an effective solution to the problems in a socially oriented economy.

Key words: administrative and legal relations, licensing, subjects, peculiarities of legal relations, protection.

\section{Література}

1. Про ратифікацію Угоди про асоціаціюо між Україною, з однієї сторони, та Європейським Союзом, Європейським співтовариством з атомної енергї $i$ їхніми державами-иленами, з іншої сторони : Закон
України від 16 вересня 2014 р. № 1678-VII. Відомості Верховної Ради України. 2014. № 40. Cm. 2021.

2. Про внесення змін до деяких законодавчих актів України щодо спрощення умов ведення бізнесу (дерегуляція) : Закон України від 12 лютого 2015 р. № 191-VIII. Відомості Верховної Ради України. 2015. № 21. Cm. 133 .

3. Про лімензування видів господарської діяльності : Закон України від 02 березня 2015 р. № 222-VIII. Відомості Верховної Ради України. 2015. № 23. Ст. 158.

4. Баженова А.А. Адміністративно-правове регулювання лічензування господарської діяльності : дис. ... канд. юрид. наук : 12.00.07. Tернопіль, 2018. 230 c.

5. Ковалів М.В., Стахура І.Б. Особливості адміністративно-правового статусу органів виконавчої влади. Вісник Національного університету «Львівська політехніка». Юридичні науки. 2014. № 807. C. 22-26.

6. Ковалів М.В., Єсімов С.С., Лозинський Ю.Р. Правове регулювання правоохоронної діяльності : навчальний посібник. Львів : ЛьвДУВС, 2018. 323 с.

7. Про Національний банк України : Закон України від 02 березня 2015 р. № 222-VIII. Відомості Верховної Ради України. 1999. № 29. Ст. 238.

8. Бортник Н.П., Єсімов С.С. Адміністративно-правові відносини при здійсненні державного фінансового адміністрування Нащіональним банком України. Вісник Національного університету «Львівська політехніка». Юридичні науки. 2015. № 827. C. 9-16.

9. Авер'янова Є.В. Правове регулювання ліщензування господарської діяльності: дис. ... канд. юрид. наук : 12.00.04. Київ, 2018. 